\title{
Estimation Leaf Area by Composite Leaves of Canavalia rosea Seedlings Through Linear Dimensions From Last Leaflet
}

\author{
Ana Paula Braido Pinheiro ${ }^{1}$, Vinicius de Souza Oliveira ${ }^{1}$, Karina Tiemi Hassuda dos Santos ${ }^{2}$, \\ Jéssica Sayuri Hassuda Santos ${ }^{2}$, Gleyce Pereira Santos ${ }^{2}$, João Vitor Garcia Silva ${ }^{2}$, Adriele dos Santos Jardim², \\ Lana Lirio Longue ${ }^{2}$, Sara Francischetto Nunes ${ }^{2}$, André Luiz Ribeiro Azeredo ${ }^{2}$, Fábio Ribeiro Pires ${ }^{2}$, \\ Adriano Alves Fernandes ${ }^{2}$, Omar Schmildt ${ }^{1}$, Marcio Paulo Czepak ${ }^{2} \&$ Edilson Romais Schmildt ${ }^{2}$ \\ ${ }^{1}$ Postgraduate Program in Tropical Agriculture, Federal University of Espírito Santo, São Mateus, ES, Brazil \\ ${ }^{2}$ Departament of Agrarian and Biological Sciences, Federal University of Espírito Santo, São Mateus, ES, Brazil \\ Correspondence: Ana Paula Braido Pinheiro, Postgraduate Program in Tropical Agriculture, Federal University \\ of Espírito Santo, São Mateus, ES, Brazil. E-mail: anabraidop@gmail.com
}

Received: March 25, 2019

doi:10.5539/jas.v11n9p299
Accepted: April 26, $2019 \quad$ Online Published: June 30, 2019

URL: https://doi.org/10.5539/jas.v11n9p299

\begin{abstract}
The objective of this work was to propose models of equations from measurements of the linear dimensions of the last leaflet for the estimation of the leaf area of the composite leaves of Canavalia rosea. For this purpose, 441 composite leaves of 198 seedlings were used, 45 days after sowing, produced in nursery and belonging to the Federal University of Espírito Santo, Campus São Mateus, located in the municipality of São Mateus, North of the State of Espírito Santo, Brazil. The length (L) along the main midrib and the maximum leaf width (W) of the last leaflet of each composite leaf, as well as the leaf area of all leaflets, were measured. Subsequently, it was determined the product of the multiplication of the length with the width (LW) and leaf area observed (OLA) from the sum of leaf area of leaflets in front of these measures were adjusted linear and non-linear equations of linear first degree, quadratic and power models, where, OLA was used as a dependent variable in function of L, $\mathrm{W}$ and LW as independent variable. Based on the models tested, we obtained equations for the estimated leaf area (ELA). The mean values of ELA and OLA were compared by Student's $t$ test $5 \%$ probability. The mean absolute error (MAE), the root mean square error (RMSE) and the Willmott $d$ index, were determined as criteria for validation. The best adjusted equation was chosen through the non-significant values in the comparison of the means of ELA and OLA, values of MAE and RMSE closer to zero, value of the index $d$ near the unitary and higher values of $\mathrm{R}^{2}$. Thus, the leaf area of the composite leaf of $C$. rosea seedlings can be estimated by the power model represented by equation ELA $=2.2951(\mathrm{LW})^{0.9474}$ quickly, easily and non-destructively.
\end{abstract}

Keywords: Canavalia rosea, mathematical models, non-destructive methods

\section{Introduction}

Canavalia rosea is a species of restinga, belonging to the family Leguminosae, popularly known as beach beans (Vatanparast, 2010). Its distribution occurs in all tropical and subtropical coastal areas of the world. Its importance varies from food consumption, until the use as fodder, fertilizers, bioactive compounds, pharmaceutical industry, soil establishment and erosion control (Sridhar \& Bhagya, 2007; Mohajer, Taha, Mohamed, \& Razak, 2017).

Due to the intense relationship between the leaves and the physiological processes, it is essential to estimate the leaf area in a simple and precise manner in ecological and agronomic studies, involving plant growth and development, light interception, photosynthetic efficiency, evapotranspiration and responses related to fertilizers and irrigation (Blanco \& Folegatti, 2005; Spann \& Heerema, 2010).

There are different ways of determining the leaf area of a plant, ranging from direct methods to indirect methods (Carvalho, Toebe, Tartaglio, Bandeira, \& Tambara, 2017). In the vast majority, direct methods are destructive 
and expensive because they require specific electronic meters (Pompelli et al., 2012). The indirect methods, are more simple and faster in their execution, besides being non-destructive, allowing successive measurements to be made over time (Gamiely, Randle, Milks, \& Smittle, 1991; Spann \& Heerema, 2010).

An of the most used methods for indirect leaf area determination is through predictive mathematical equation models of the actual leaf area as a function of linear leaf dimensions and their respective combinations (Gamiely et al., 1991; Blanco \& Folegatti, 2005). However, it is necessary to adjust mathematical models for each species of interest (Spann \& Heerema, 2010).

In this way, are notorious the great number of works involving mathematical equations as non-destructive method to estimate the leaf area in a wide range of vegetal species as Cucumis sativus L. (Cho, S. Oh, M. M. Oh, \& Son, 2007), Helianthus annuus L. (Rouphael, Colla, Fanasca, \& Karam, 2007), Jatropha curcas (Pompelli et al., 2012), Vitis vinifera L. (Buttaro, Rouphael, Rivera, Colla, \& Gonnella, 2015), Coffea canephora (Schmildt, Amaral, Santos, \& Schmildt, 2015), Rosa hybrida L. (Costa, Pôças, \& Cunha, 2016), Crotalaria juncea (Carvalho et al., 2017), Prunus armeniaca L. (Cirillo et al., 2017), Litchi chinensis Sonn (Oliveira, Silva, Costa, Schmildt, \& Vitória, 2017), guava (Vitória et al., 2018), Carica papaya L. (Oliveira et al., 2019) and Plectranthus barbatus Andrews (Ribeiro et al., 2019).

However, studies involving species of Brazilian restinga are scarce, in addition, the determination of the leaf area of the composite leaves can be laborious and time consuming due to the large number of leaflets that need to be measured. Thus, the objective of this study was to propose mathematical equations using measurements of the linear dimensions of the last leaflet for the estimation of the leaf area of the composite leaves of C. rosea.

\section{Method}

For the accomplishment of the present study were used 441 leaves composed of 198 Canavalia rosea seedlings obtained in nursery,belonging to the Federal University of Espírito Santo, Campus São Mateus, located in the municipality of São Mateus, North of the State of Espírito Santo, Brazil, with geographic coordinates of $18^{\circ} 40^{\prime} 36^{\prime \prime}$ south latitude and $39^{\circ} 51^{\prime} 35^{\prime \prime}$ longitude East. The climate of the region according to the classification of köppen is tropical type AW (tropical humid), with rains in summer and dry winter (Alvares, Stape, Sentelhas, Gonçalves, \& Sparovek, 2014).

The seeds used were obtained from the Socio-Cultural and Environmental Center José Bahia, located in the municipality of São Mateus, North of the State of Espírito Santo, Brazil. For the preparation of the seedlings was used a tube with volume of $290 \mathrm{~cm}^{3}$ filled with substrate based on sand, clay and coconut fiber. The irrigation was done by a localized sprinkler system with an $8 \mathrm{~mm} \mathrm{~d}^{-1}$ irrigation depth and a 1 hour irrigation frequency, distributed in four 15 minute applications. The seedlings were kept in a greenhouse covered with sombrite ${ }^{B}$ screen of $30 \%$ shading until they were completed 45 days after sowing.

In the laboratory, the last leaflet of the 441 composite leaves of $C$. rosea was measured. Each composite sheet was scanned in HP Deskjet $F 4280^{\circledR}$ Scanner and the images saved in TIF format with 75 dpi, each sheet was composed of 3 leaflets. The length (L) along the main midrib and the maximum width (W) were measured in $\mathrm{cm}$ of the last leaflet of each composite leaf (Figure 1), as well as the leaf area of all leaflets with the help of the Image ${ }^{\circledR}$ program (Schindelin, Rueden, Hiner, \& Eliceiri, 2015). The product of length and width (LW) was obtained by multiplying $\mathrm{L}$ and $\mathrm{W}$ and observed leaf area $\left(\mathrm{OLA}\right.$, in $\left.\mathrm{cm}^{2}\right)$ from the sum of leaf area of leaflets. 


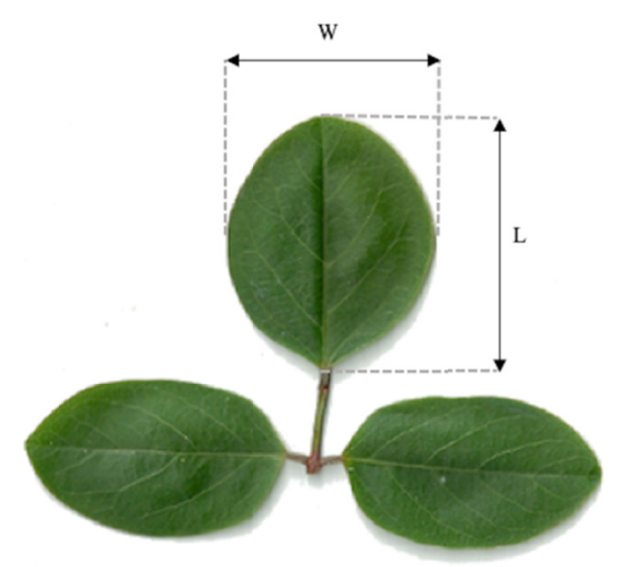

Figure 1. Representation of the length (L) along the midrib and the maximum leaf width (W) of the last leaflet of leaves of Canavalia rosea seedlings

Data were submitted to descriptive statistics analysis, obtaining the minimum, maximum, mean, amplitude and coefficient of variation (CV) values. For the estimation of the leaf area of the composite leaves of $C$. rosea through the dimensions of the last leaflet, nine modeling equations were obtained from the sample of 396 composite leaves. For this purpose, the first degree linear models represented by ELA $=\widehat{\beta}_{0}+\widehat{\beta}_{1} x$, quadratic represented by ELA $=\widehat{\beta}_{0}+\widehat{\beta}_{1} x+\widehat{\beta}_{2} x^{2}$, and power represented by ELA $=\widehat{\beta}_{0} x^{\hat{\beta}_{1}}$, in which OLA was used with dependent variable in function of $\mathrm{L}, \mathrm{W}$ and $\mathrm{LW}$ as independent variables (x).

The validation of the data was based on the sample of 45 separate composite leaves for this purpose. All values of L, W and LW were substituted in the equations adjusted for modeling, obtaining the estimated leaf area (ELA), in $\mathrm{cm}^{2}$. A simple linear equation model was then fitted for each proposed model, where ELA was used dependent variable in function of OLA. Subsequently, the mean values of ELA and OLA were compared by Student's $t$ test with a $5 \%$ probability. The mean absolute error (MAE), the root mean square error (RMSE) and the Willmott $d$ index (Willmott, 1981), for all equations were also determined by Equations 1, 2 and 3.

$$
\begin{gathered}
\mathrm{EAM}=\frac{1}{\mathrm{n}-1} \sum_{\mathrm{i}=1}^{\mathrm{n}}|\mathrm{ELA}-\mathrm{OLA}| \\
\mathrm{RQME}=\sqrt{\frac{1}{\mathrm{n}-1} \sum_{\mathrm{i}=1}^{\mathrm{n}}(\mathrm{ELA}-\mathrm{OLA})^{2}} \\
\mathrm{~d}=1-\left[\frac{\sum_{\mathrm{i}=1}^{\mathrm{n}}\left(\mathrm{ELA}_{\mathrm{i}}-\mathrm{OLA}_{\mathrm{i}}\right)^{2}}{\sum_{\mathrm{i}=1}^{\mathrm{n}}\left(\left|\mathrm{ELA}_{\mathrm{i}}-\overline{\mathrm{OLA}}\right|+\left|\mathrm{OLA}_{\mathrm{i}}-\overline{\mathrm{OLA}}\right|\right)^{2}}\right]
\end{gathered}
$$

where, ELA, are the values of the estimated leaf area; OLA, values of leaf area observed; $n$ the number of leaves contained in the sample for validation, where $\mathrm{n}=45$, in the present study.

The criteria used to determine the best model for the estimation of the C. rosea leaf area were based on the non-significant values of the comparison of the means of ELA and OLA, values of MAE and RMSE closer to zero and index $d$ closest to the unit. All the statistical analyzes were performed in the software $\mathrm{R}$ (R Core Team, 2018), through the data package ExpDes.pt version 1.2 (Ferreira, Cavalcanti, \& Nogueira, 2018).

\section{Results and Discussion}

The leafs sampled for model adjustment and data validation presented a high amplitude for length (L), width (W), product of length with width (LW) and leaf area observed (Table 1). The high amplitude can be proven due to the high variability of the data, surpassing the $22 \%$ for all the characteristics. These values are considered according to the classification of Pimentel-Gomes (2009) as high or very high. However, this high variability is fundamental in obtaining mathematical models, since the selected equation allows to estimate the leaf area for leafs of various sizes, always respecting the limits of the values analyzed (Oliveira et al., 2017). 
Note that the L, W, LW and OLA values of the sampling used for the validation are within the range of the values used to perform the modeling. This finding is important because according to Levine, Stephan, and Szabat (2017), the values used for validation can not extrapolate the values used for the modeling adjustments.

Table 1. Minimum, maximum, average, amplitude and coefficient of variation (CV) values of the variables: length (L); width (W); product of the length and width (LW) and observed leaf area (OLA) of leaves of Canavalia rosea seedlings

\begin{tabular}{lllllll}
\hline Variable & Unit & Minimum & Maximum & Average & Amplitude & CV (\%) \\
\hline 396 leaves were used for modeling & & & & & \\
L & $\mathrm{cm}$ & 1.58 & 8.15 & 4.96 & 6.57 & 25.02 \\
$\mathrm{~W}$ & $\mathrm{~cm}$ & 1.13 & 6.44 & 4.25 & 5.31 & 27.45 \\
LW & $\mathrm{cm}^{2}$ & 1.92 & 51.90 & 22.49 & 49.98 & 44.83 \\
OLA & $\mathrm{cm}^{2}$ & 3.50 & 96.06 & 43.57 & 92.56 & 44.02 \\
45 leaves for validation & & & & & \\
L & $\mathrm{cm}$ & 1.94 & 7.42 & 5.21 & 5.50 & 22.35 \\
W & $\mathrm{cm}$ & 1.34 & 6.26 & 4.51 & 4.92 & 24.49 \\
LW & $\mathrm{cm}^{2}$ & 2.61 & 45.26 & 24.64 & 42.65 & 39.52 \\
OLA & $\mathrm{cm}^{2}$ & 4.33 & 88.08 & 47.64 & 83.75 & 38.55 \\
\hline
\end{tabular}

Note. Through the scatter diagram (Figure 2) that there was a linear and non-linear association for OLA as a function of L, W, and LW. This behavior was observed by Carvalho et al. (2017) studying the leaf area estimation for Crotalaria juncea, suggesting that linear and non-linear models should be generated and tested in these cases. Thus, in the present study, linear model of first degree, quadratic and power were adjusted for each analyzed dimension. 


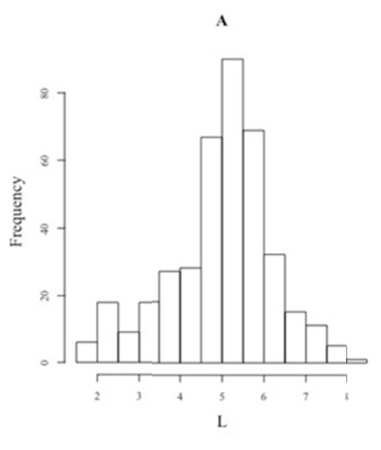

E

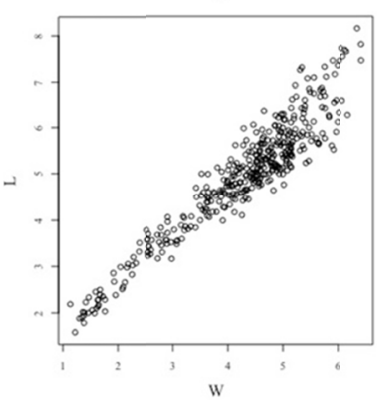

$\left(\frac{100}{20}\right.$

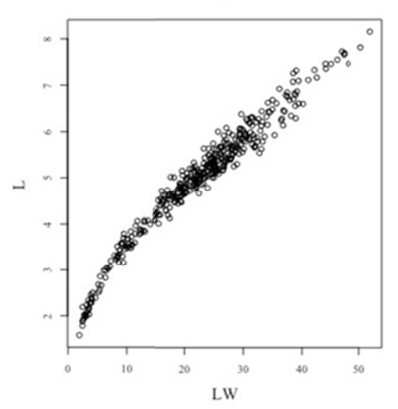

$\mathbf{M}$

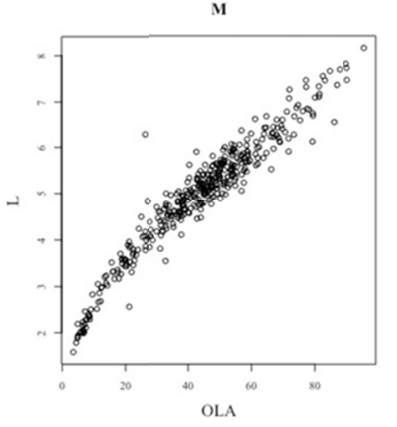

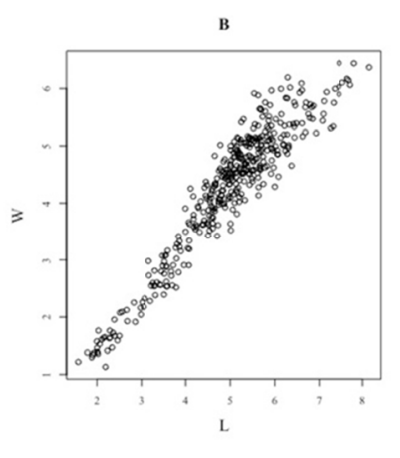

$\mathbf{F}$

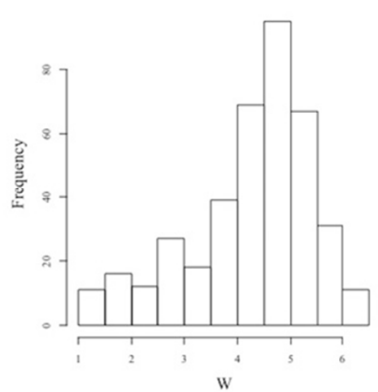

J

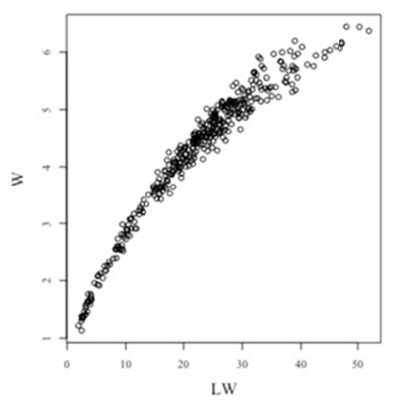

N

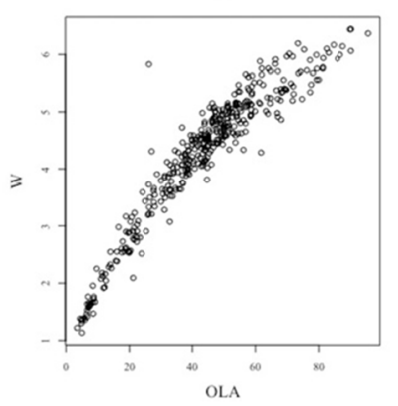

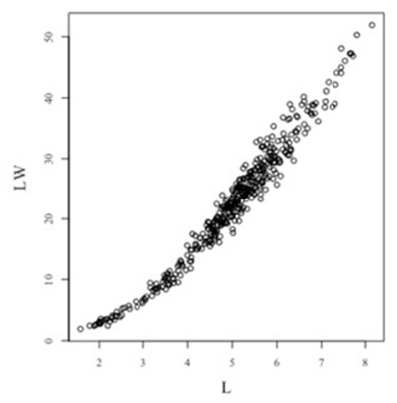

G

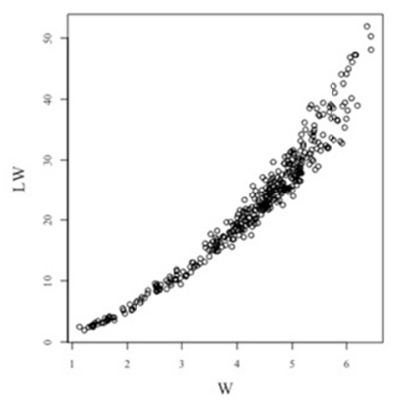

K
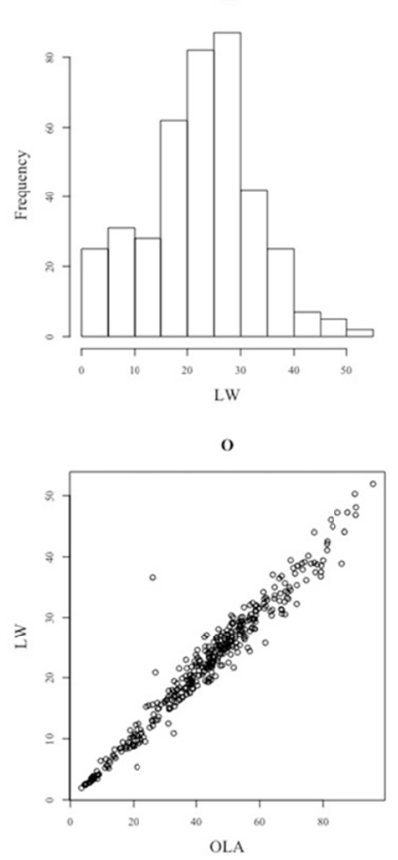

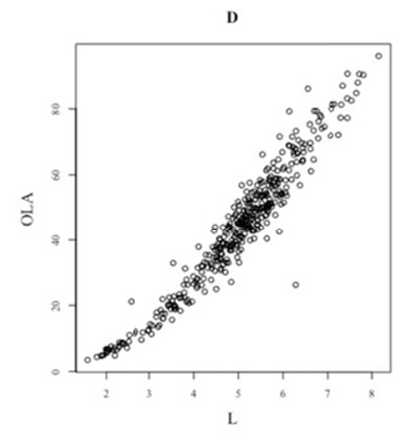

H

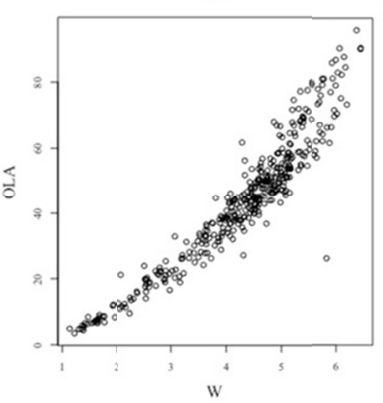

$\mathbf{L}$
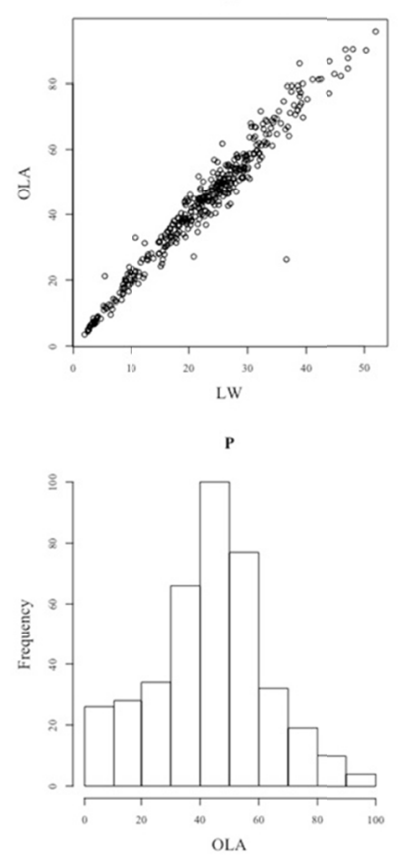

Figure 2. Frequency Histogram and distribution graphic

Table 2 shows the equations of the C. rosea leaf area estimation models. Note that the best adjustments were using LW as independent variable, with $\mathrm{R}^{2}$ greater than 0.95 . Note also that the equations based on OLA as dependent variable in function of $\mathrm{L}$ and $\mathrm{W}$ did not present a good fit. Lower values of $\mathrm{R}^{2}$ based on only one measure as independent variables were also found by Buttaro et al. (2015) and Oliveira et al. (2017) noting that these variables do not have a good relationship with OLA. However, as suggested by Antunes, Pompelli, Carretero, and Damatta (2008), mathematical equations should not be chosen only by the higher value of $\mathrm{R}^{2}$ 
because this practice can cause erroneous estimations of the leaf area. In this way, the validation of the models through appropriate methods becomes indispensable to estimate the leaf area with precision (Fascella, Darwich, \& Rouphael, 2013).

Table 2. Equation with linear adjustment of first degree, quadratic and power and its respective coefficient of determination (R2) using the observed leaf area (OLA) as dependent variable, as a function of length (L), width (W), product of length with width (LW) of leaves composed of seedlings of Canavalia rosea

\begin{tabular}{lll}
\hline Model & Equation & $\mathrm{R}^{2}$ \\
\hline Linear & $\mathrm{ELA}=-30.1381+14.8531(\mathrm{~L})$ & 0.9246 \\
Linear & $\mathrm{ELA}=-22.2932+15.4773(\mathrm{~W})$ & 0.8890 \\
Linear & $\mathrm{ELA}=1.76473+1.85898(\mathrm{LW})$ & 0.9552 \\
Quadratic & $\mathrm{ELA}=-13.8766+7.3285(\mathrm{~L})+0.8056(\mathrm{~L})^{2}$ & 0.9331 \\
Quadratic & $\mathrm{ELA}=0.07305+2.20261(\mathrm{~W})+1.75252(\mathrm{~W})^{2}$ & 0.9114 \\
Quadratic & $\mathrm{ELA}=0.791287+1.967282(\mathrm{LW})-0.002408(\mathrm{LW})^{2}$ & 0.9555 \\
Power & $\mathrm{ELA}=2.3289(\mathrm{~L})^{1.8030}$ & 0.9268 \\
Power & $\mathrm{ELA}=3.1761(\mathrm{~W})^{1.7720}$ & 0.9121 \\
Power & $\mathrm{ELA}=2.2951(\mathrm{LW})^{0.9474}$ & 0.9555 \\
\hline
\end{tabular}

After the validation of the data based on the 45 leaves sampling of $C$. rosea, it was verified that of the nine equations, those that use LW as independent variable presented higher values of $\mathrm{R}^{2}$, being the equation power model slightly higher than the linear models of first degree and quadratic. This same equation was the with the highest $\mathrm{R}^{2}$ value in the modeling adjustment, giving a better correlation between OLA and ELA (Table 3 ).

Note in Figure 3 that models involving a single measurement were less acceptable in the C. rosea leaf area estimate due to its lower $\mathrm{R}^{2}$ values. In addition, the equations based on $\mathrm{L}$ and $\mathrm{W}$ individually presented MAE and RMSE values that were farther from zero and values of the Willmott $d$ index more distinct to one, when compared the models using LW (Table 3), these criteria should be used to select the model that best fits the leaf area estimate (Oliveira et al., 2017). It was also verified that the comparative means of OLA and ELA did not statistically differ by Student's t test at 5\% of probability in all proposed models (Table 3 ), attesting a good similarity of the means of OLA and ELA. 
A

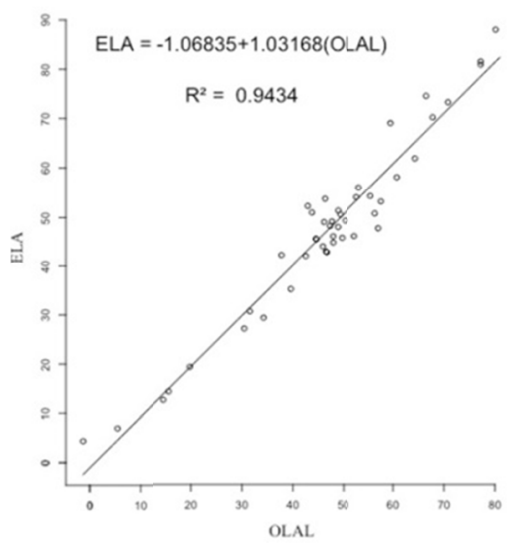

D

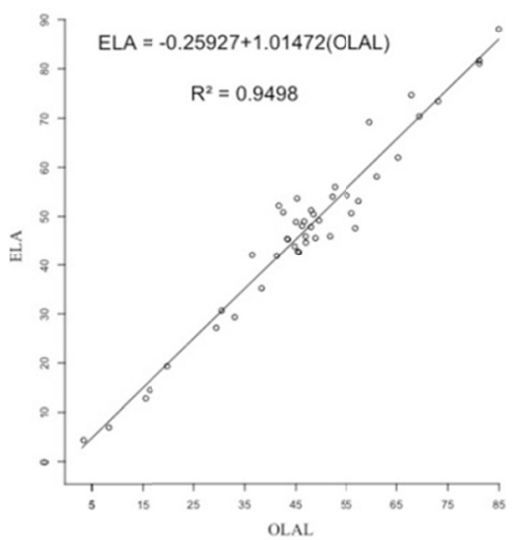

G

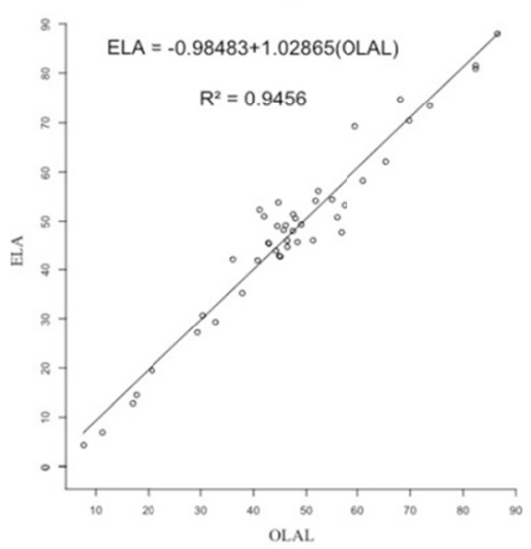

B

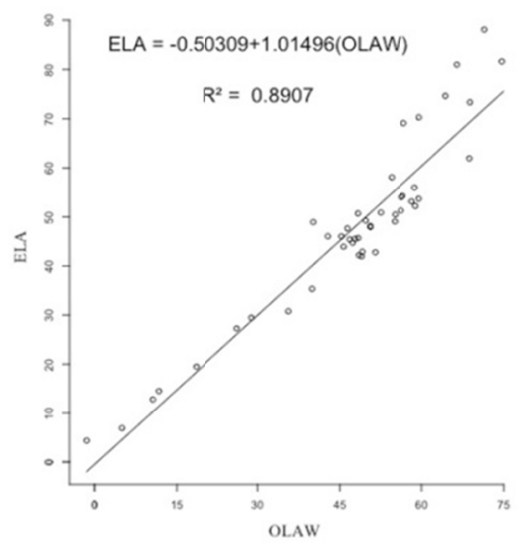

E

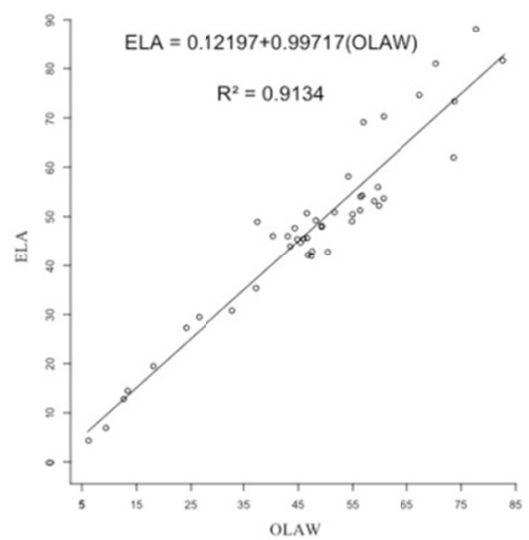

H

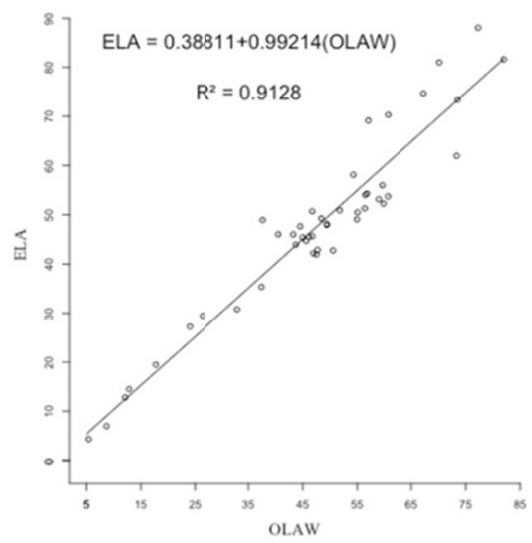

C

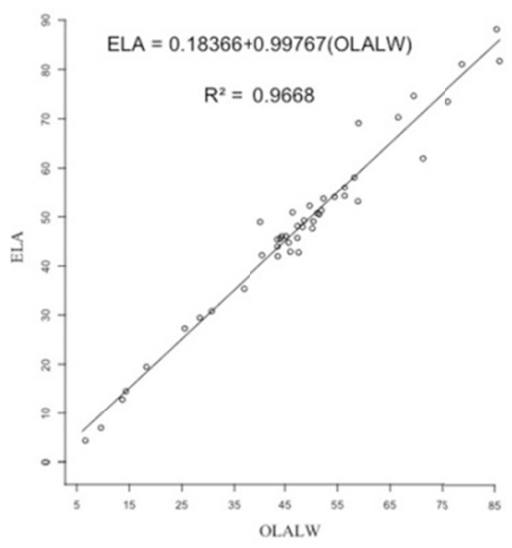

F

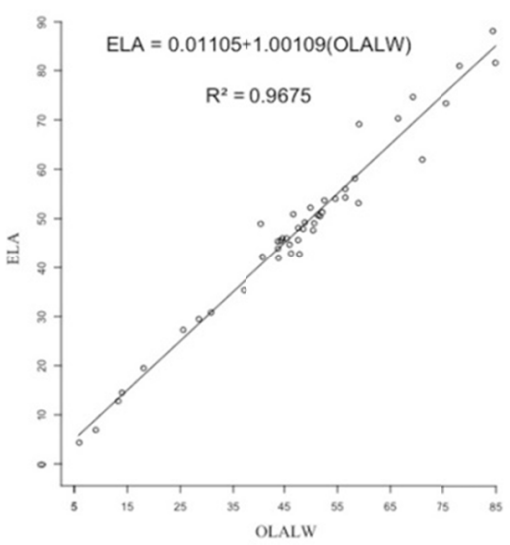

1

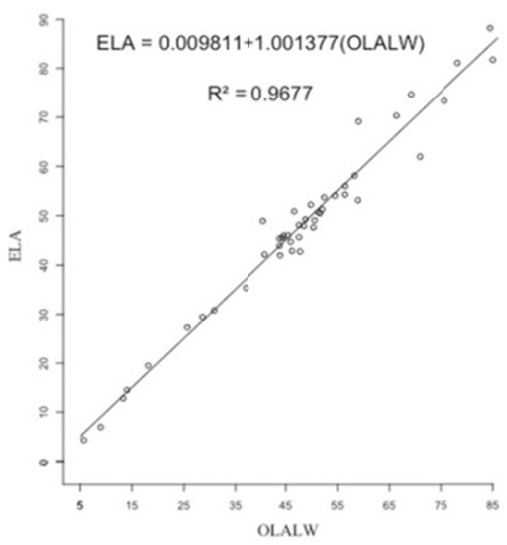

Figure 2. First degree linear adjustment validation equation and its respective determination coefficient $\left(\mathrm{R}^{2}\right)$ using the estimated leaf area (ELA) as the dependent variable obtained by first degree linear modeling equations (A, B and C), quadratic (D, E and F) and power ( $\mathrm{G}, \mathrm{H}$ and $\mathrm{I})$, as a function of leaf length observed (OLAL), width (OLAW) and length product with width (OLALW) of Canavalia rosea leaf 
Table 3. Observed leaf area (OLA) and estimated leaf area (ELA) of linear equations of first degree, quadratic and potential for the independent variables length (L), width (W) and product of length and width (LW), besides the value of $\mathrm{p}$, mean absolute error (MAE), root mean square error (RMSE) and Willmott $\mathrm{d}$ index of leaves composed of Canavalia rosea seedlings used for validation

\begin{tabular}{|c|c|c|c|c|c|c|c|}
\hline Model & Variable & OLA & ELA & $p^{*}$ value & MAE & RMSE & d \\
\hline Linear & $\mathrm{L}$ & & 47.2185 & 0.9098 & 3.6051 & 4.4253 & 0.9844 \\
\hline Linear & W & & 47.4392 & 0.956 & 4.8565 & 6.0831 & 0.9698 \\
\hline Linear & LW & & 47.5732 & 0.9849 & 2.3970 & 3.3462 & 0.9915 \\
\hline Quadratic & $\mathrm{L}$ & & 47.2105 & 0.9090 & 3.1609 & 4.1481 & 0.9866 \\
\hline Quadratic & W & 47.6460 & 47.6589 & 0.9973 & 4.2078 & 5.4048 & 0.9769 \\
\hline Quadratic & LW & & 47.5830 & 0.9870 & 2.3798 & 3.3126 & 0.9916 \\
\hline Power & $\mathrm{L}$ & & 47.2762 & 0.9221 & 3.4032 & 4.3306 & 0.9852 \\
\hline Power & W & & 47.6322 & 0.9971 & 4.2236 & 5.4267 & 0.9768 \\
\hline Power & LW & & 47.5707 & 0.9844 & 2.3601 & 3.3047 & 0.9917 \\
\hline
\end{tabular}

Note. ${ }^{*} P$ values higher than 0.05 indicate that the observed leaf area (OLA) and the estimated leaf area (ELA) do not differ by Student t-test.

The use of only a linear dimension in practice is easier to execute, making the work less costly. However, these models are adjusted only for specific cases, being less precise for most species (Espindula et al., 2018). Therefore, models using the relation of linear dimensions as found in this study are notoriously used as reported for several species as Jatropha curcas (Pompelli et al., 2012), Vitis vinífera L. (Buttaro et al., 2015), Coffea canephora (Schmildt et al., 2015), Crotalaria juncea (Carvalho et al., 2017) and Litchi chinensis Sonn (Oliveira et al., 2017).

Thus, the power model equation represented by ELA $=2.2951(\mathrm{LW})^{0.9474}$ based on the product of length and width as independent variable, can be used to estimate the leaf area of Canavalia rosea with better precision. These variables can be measured quickly, without the need to use specific and costly equipment, and after the establishment of the model, the mathematical equations can be used for further research without the obligation of destroying new leafs for the establishment of new models (Spann \& Heerema, 2010).

\section{Conclusion}

It is possible to conclude that the leaf area of Canavalia rosea seedlings can be measured with better precision through the product of the length multiplication along the main midrib with the maximum width of the leaf (LW) of the last leaflet, from the model power represented by the equation ELA $=2.2951(\mathrm{LW})^{0.9474}$, quickly, easily and non-destructively.

\section{Acknowledgements}

CNPq, CAPES and FAPES for financial support.

\section{References}

Alvares, C. A., Stape, J. L, Sentelhas, P. C., Gonçalves, J. L. M., \& Sparovek, G. (2014). Köppen’s climate classification map for Brazil. Meteorologische Zeitschrift, 22(6), 711-728. https://oi.org/10.1127/ 0941-2948/2013/0507

Antunes, W. C., Pompelli, M. F., Carretero, D. M., \& Damatta, F. M. (2008). Allometric models for nondestructive leaf area estimation in coffee (Coffea arabica and Coffea canephora). Annals of Applied Biology, 153(1), 33-40. https://doi.org/10.1111/j.1744-7348.2008.00235

Buttaro, D., Rouphael, Y., Rivera, C. M., Colla, G., \& Gonnella, M. (2015). Simple and accurate allometric model for leaf area estimation in Vitis vinifera L. genotypes. Photosynthetica, 53(3), 342-348. https://doi.org/10.1007/s11099-015-0117-2

Blanco, F. F., \& Folegatti, M. V. (2005). Estimation of leaf area for greenhouse cucumber by linear measurements under salinity and grafting. Scientia Agricola, 62(4), 305-309. https://oi.org/10.1590/ S0103-90162005000400001 
Carvalho, J. O., Toebe, M., Tartaglio, F. L., Bandeira, C. T., \& Tambara, A. L. (2017). Leaf area estimation from linear measurements in different ages of Crotalaria juncea plants. Anais da Academia Brasileira de Ciencias, 89(3), 1851-1868. https://doi.org/10.1590/0001-3765201720170077

Cirillo, A., Pannico, A., Basile, B., Rivera, C. M., Giaccone, M., Colla, G., Pascale, S., \& Rouphael, Y. (2017). A simple and accurate allometric model to predict single leaf area of twenty-one European apricot cultivars. European Journal of Horticultural Science, 82(2), 65-71. https://doi.org/10.17660/eJHS.2017/82.2.1

Cho, Y. Y., Oh, S., Oh, M. M., \& Son, J. E. (2007). Estimation of individual leaf area, fresh weight, and dry weight of hydroponically grown cucumbers (Cucumis sativus L.) using leaf length, width, and SPAD value. Scientia Horticulturae, 111(4), 330-334. https://doi.org/10.1016/j.scienta.2006.12.028

Costa, A. P., Pôças, I., \& Cunha, M. (2016). Estimating the leaf area of cut roses in different growth stages using image processing and allometrics. Horticulturae, 2(6), 1-10. https://doi.org/10.3390/horticulturae2030006

Espindula, M. C., Passos, A. M. A., Araújo, L. F. B., Marcolan, A. L., Partelli, F. L., \& Ramalho, A. R. (2018). Indirect estimation of leaf area in genotypes of 'Conilon' coffee (Coffea canephora Pierre ex A. Froehner). Australian Journal of Crop Science, 12(6), 990-994. https://doi.org/10.21475/ajcs.18.12.06.PNE1090

Fascella, G., Darwich, S., \& Rouphael, Y. (2013). Validation of a leaf area prediction model proposed for rose. Chilean Journal of Agricultural Research, 73(1), 73-76. https://doi.org/10.4067/S0718-583920130001 00011

Ferreira, E. B., Cavalcanti, P. P., \& Nogueira, D. A. (2018). Package 'ExpDes.pt'.

Gamiely, S., Randle, W. M., Milks, W. A., \& Smittle, D. A. (1991). A rapid and non- destructive method for estimating leaf area of onions. Hortscience, 26(2), 206. https://doi.org/10.21273/HORTSCI.26.2.206

Levine, D. M., Stephan, D. F., \& Szabat, K. A. (2017). Estatistic for managers using Microsoft Excel: Global edition (8th ed., p. 728). London: Person.

Mohajer, S., Taha, R. M., Mohamed, N., \& Razak, U. N. A. (2017). Baybean (Canavalia rosea (Sw.) DC.); organogenesis, morphological and anatomical studies. Gayana Botanica, 74(1), 120-130. https://doi.org/ $10.4067 / \mathrm{S} 0717-66432017005000321$

Oliveira, P. S., Silva, W., Costa, A. A. M., Schmildt, E. R., \& Vitória, E. L. (2017). Leaf area estimation in litchi by means of allometric relationships. Revista Brasileira de Fruticultura, 39(Special), 1-6. https://doi.org/ $10.1590 / 0100-29452017403$

Oliveira, V. S., Santos, K. T. H., Ambrósio, T. J., Santos, J. S. H., Santana, W. R., Malikouski, R. G., ... Schmildt, E. R. (2019). Mathematical Modeling for Leaf Area Estimation from Papaya Seedlings 'Golden THB'. Journal of Agricultural Science, 11(4), 496-505. https://doi.org/10.5539/jas.v11n5p496

Pimentel-Gomes, F. (2009). Curso de estatística experimental (15th ed.). Piracicaba, SP: Fealq.

Pompelli, M. F., Antunes, W. C., Ferreira D. T. R. G., Cavalcante, P. G. S., Wanderley Filho, H. C. L., \& Endres, L. (2012). Allometric models for non-destructive leaf area estimation of Jatropha curcas. Biomass and Bioenergy, 36, 77-85. https://doi.org/10.1016/j.biombioe.2011.10.010

R Core Team. (2018). R: A language and environment for statistical computing. Vienna: R Foundation for Statistical Computing, Vienna, Austria.

Ribeiro, A. M. S., Mundim, D. A., Mendonça, D. C., Santos, K. T. H. Santos, J. S. H., Oliveira, V. S., ... Schmildt E. R. (2019). Leaf Area Estimation of Garden Boldo from Linear Dimensions. Journal of Agricultural Science, 11(4), 461-469. https://doi.org/10.5539/jas.v10n12p272

Rouphael, Y., Colla, G., Fanasca, S., \& Karam, F. (2007). Leaf area estimation of sunflower leaves from simple linear measurements. Photosynthetica, 45(2), 306-308. https://doi.org/10.1007/s11099-007-0051-z

Schindelin, J., Rueden, C. T., Hiner, M. C., \& Eliceiri, K. W. (2015). The ImageJ Ecosystem: An Open Platform for Biomedical Image Analysis. Molecular Reproduction and Development, 82(7-8), 518-529. https://doi.org/10.1002/mrd.22489 
Schmildt, E. R., Amaral, J. A. T., Santos, J. S., \& Schmildt, O. (2015). Allometric model for estimating leaf area in clonal varieties of coffee (Coffea canephora). Revista Ciência Agronômica, 46(4), 740-748. https://doi.org/10.5935/1806-6690.20150061

Spann, T. M., \& Heerema, R. J. (2010). A simple method for nondestructive estimation of total shoot leaf area in tree fruit crops. Scientia Horticulturae, 125(3), 528-533. https://doi.org/10.1016/j.scienta.2010.04.033

Sridhar, K. R., \& Bhagya, B. (2007). Coastal sand dune vegetation: A potential source of food, fodder and pharmaceuticals. Livestock Research for Rural Development, 19(6), 84-89.

Vatanparast, M. (2010). Phylogeography of a pantropical plant with sea-drifted seeds; Canavalia rosea (Sw.) DC., (Fabaceae) (p. 89). Graduate School of Science, Chiba University.

Vitória, E. L., Freitas, I. L. J, Locatelli, T., Lacerda, E. G., Valle, J. M., Pereira, R. C., ... Fernandes, A. A. (2018). Mathematical Models for Leaf Area Estimates of Guava. Journal of Agricultural Science, 10(12), 272-278. https://doi.org/10.5539/jas.v10n12p272

Willmott, C. J. (1981). On the validation of models. Physical Geography, 2(2), 184-194. https://doi.org/10.1080/ 02723646.1981 .10642213

\section{Copyrights}

Copyright for this article is retained by the author(s), with first publication rights granted to the journal.

This is an open-access article distributed under the terms and conditions of the Creative Commons Attribution license (http://creativecommons.org/licenses/by/4.0/). 